\title{
CHANGES IN THE AQUATIC MOSS SPHAGNUM DENTICULATUM BRID. POPULATION ABUNDANCE IN A SOFTWATER LAKE OVER A PERIOD OF THREE YEARS
}

\author{
JÓZEF SZMEJA \\ Department of Plant Ecology, University of Gdańsk \\ Al. Legionów 9, 80-441 Gdańsk, Poland \\ e-mail: j.szmeja@ug.edu.pl
}

(Received: November 12, 2009. Accepted: March 23, 2010)

\begin{abstract}
Changes in population abundance of submerged Sphagnum denticulatum Brid. were studied in an acidic and oligotrophic lake in NW Poland over three years. Individuals were counted in a moss carpet at a depth of $2.5 \mathrm{~m}$ on 4 experimental plots, $1 \times 1 \mathrm{~m}$ each, every 30 days for 36 months using the SCUBA method. PAR intensity was seasonally variable (in winter higher than in summer). Changes in water $\mathrm{pH}$, conductivity, $\mathrm{HCO}_{3}{ }^{-}$concentration, hydration and sediment $\mathrm{pH}$ were statistically insignificant $(\mathrm{p}>0.05)$. In the summer of the second study year the moss carpet disappeared almost completely due to a massive bloom of filamentous green algae.

Periods of growth, regression and regeneration were observed in the population. The stabilisation of population size took 24 months and followed the pattern: slight fluctuations, then rapid growth and repetition of slight fluctuations. The first stage lasted nine, the second four and the third nine months. These stages took place irrespective of seasons, temperature or PAR intensity. Each rapid increase in abundance lasted about 30 days, at PAR intensity $>20 \%$ and water temperature ranging from 11 to $16^{\circ} \mathrm{C}$ (in winter, spring or autumn). The regression stage brought about by the algal bloom started in the second year (in summer) and lasted six months (until the end of January in the third year). The population regeneration began in winter (in February, water temperature $3.0^{\circ} \mathrm{C}$, PAR about $20 \%$, ice cover $0.15 \mathrm{~m}$ ) and finished with the end of spring. The population of $S$. denticulatum shows a repetitive pattern of abundance variations, which is seriously disturbed in summer, especially after a warm spring, by a massive bloom of filamentous green algae.
\end{abstract}

KEY WORDS: Sphagnum denticulatum, aquatic moss, population dynamics, phenology, softwater lake.

\section{INTRODUCTION}

Mosses are a common element of submerged vegetation in softwater lakes of northern Europe. They are mixed with higher plants or charophytes (Sand-Jensen and Søndergaard 1981; Chambers and Kalff 1985; Szmeja and Clément 1990), especially in oligotrophic lakes (Srivastava et al. 1995; Toivonen and Huttunen 1995; Murphy 2002). They often occur in great numbers in anthropogenically acidified lakes (Roelofs 1983 and Arts 1987; Catling et al. 1986).

The macroscopic vegetation of lakes is to a great extent composed of perennials of which the phenology or population dynamics and structure, except for some species, have not been studied in detail. One of such water plants is Sphagnum denticulatum Brid. (syn.: S. auriculatum Schimp.). This species is fairly common e.g. in the Scandinavian Peninsula, northwestern Russia (Karelia Republic), British Isles and coastal regions of the North and West European Plain (Murphy 2002), as well as some mountains including the eastern Pyrenees (Gacia et al. 1994).
In the north of Poland (Pomerania) S. denticulatum occupies acidic calcium-poor lakes which are often rich in humic substances (Szmeja 2000; Szmeja et al. 2001; Banaś 2002; Szańkowski and Kłosowski 2004). If the concentration of humic substances in water rises from 0.5 to $25 \mathrm{mg} \mathrm{C}$ $\mathrm{dm}^{-3}$, the settlement index of the population area of this plant in the lakes of north-western Poland falls from 39.3 to $7.2 \mathrm{~g} \mathrm{d.w.} \mathrm{m}^{-2}$ (Szmeja and Bociąg 2004). S. denticulatum grows in a wide depth range, from 1 (2) to 9 (12) $\mathrm{m}$, on an acidic and highly hydrated organic substrate. In the shallow littoral (to 3 (4) $\mathrm{m}$ ) it forms communities with a small addition of other mosses, such as Warnstorfia exannulata (Schimp. in B.S.G.) Loeske, Sphagnum cuspidatum Ehrh. ex Hoffm. and S. fallax (Klinggr.) Klinggr. On the other hand, in the deep littoral single-species aggregations of this plant are dominant. The percentage of Cormophyta in this plant's aggregations, especially below the depth of 4 (5) $\mathrm{m}$, is generally very low. In shallow and small softwater lakes, $S$. denticulatum occupies a considerable part of the bottom, forming vast, dense and weakly 
anchored carpets. In shallow water (1-2 m), they are sensitive to hydrodynamic disturbances, e.g. wave action, and most often due to this fact the carpets are small and scattered. In deep water, however, they are much bigger and more resistant, but grow under conditions of light and oxygen deprivation.

The studied Lake Gacno Wielkie is located on an extensive outwash plain from the time of the last glaciation covered mainly with pinewood. This is a forest area with numerous lakes, streams and wetlands, especially peat bogs, to a small extent covered with a cultural landscape. The mean annual air temperature is $+7.1^{\circ} \mathrm{C}$; July is the warmest month $\left(+16.7^{\circ} \mathrm{C}\right)$, and January the coldest $\left(-2.6^{\circ} \mathrm{C}\right)$. The area receives the annual precipitation total of $577 \mathrm{~mm}$. It has the lowest precipitation in winter (February), and the greatest at the height of summer (July). The catchment is dominated by sandy soils which are poor in nitrogen and phosphorus, very acidic and have very low buffer and sorptive properties (Chmara 2008).

The population abundance of submerged macrophytes depends on many phenomena and processes in the population itself, the communities, the lake, and even its catchment (Szmeja 2006). It is assumed that population abundance is determined by availability of nutrients, light intensity, and interspecific and intrapopulational competition. However, genetic diversity of individuals, which results from the differently programmed general-purpose genotypes and single-purpose genotypes, sensu Barrett et al. (1993), probably affects the abundance only to a lesser extent. Only the fact that this plant propagates vegetatively supports the assumption that $S$. denticulatum individuals lack significant genetic diversity, which could influence the population dynamics. It should be mentioned that genetic variability of aquatic plants, even as a regulator of their phenotypic plasticity, is of rather secondary importance in local populations (Hofstra et al. 1995; Akimoto et al. 1998; Gornall et al. 1998; Gao and Hong 2000; Santamaría 2002).

The aim of this work is to analyse the population abundance of $S$. denticulatum over three years in a small acidified clear-water and softwater lake with a well-preserved catchment covered with pine forest in north-western Poland.

\section{METHODS}

The fieldwork was carried out in Lake Gacno Wielkie (NW Poland, approx. $120 \mathrm{~km}$ to the south-west of the Gulf of Gdańsk, in Tuchola Pine Forest National Park), for 36 months, from August 2004 to July 2007, on four permanent experimental plots, $1 \times 1 \mathrm{~m}$ each, divided into quadrats of $0.2 \times 0.2 \mathrm{~m}$, at a depth of $2.5 \mathrm{~m}$. The plots were located in a characteristically developed moss carpet. On the plots $S$. denticulatum individuals were counted, and water temperature $\left(\mathrm{C}^{\circ}\right), \mathrm{pH}$, conductivity $\left(\mu \mathrm{S} \mathrm{cm}^{-1}\right)$ and colour $(\mathrm{mg} \mathrm{Pt}$ $\mathrm{dm}^{-3}$ ), PAR intensity (\% of light reaching the population) and $\mathrm{HCO}_{3}{ }^{-}$concentration $\left(\mathrm{mg} \mathrm{dm}^{-3}\right)$ were measured. Once a month, adjacent to the plots, sediment samples were also collected into plastic containers of $250 \mathrm{~cm}^{3}$ (144 samples in total). Conductivity $\left(\mu \mathrm{S} \mathrm{cm}^{-1}\right), \mathrm{pH}$ and redox potential $(\mathrm{mV})$ were determined in the sediment samples. All the measurements were performed according to recommendations of Wetzel and Likens (1991), Hermanowicz et al. (1999) and Eaton et al. (2005). The significance of differences between the water samples, as well as the sediment ones, was tested by ANOVA (Kruskal-Wallis test; Lomnicki 1999) for $\mathrm{p}<0.05$. The rate of population growth (PGR; individuals $\mathrm{m}^{-2}$ month $^{-1}$ ) was calculated from the difference between the numbers of individuals on the 4 plots $\left(4 \mathrm{~m}^{2}\right)$ in month $b$ and the previous one $a$.

\section{RESULTS}

\section{Environmental conditions}

Lake Gacno is small (13.5 ha), shallow (5.5 m), oligotrophic, acidic, softwater, legally protected and free from any significant human-induced pressure. The studied population occurs at a depth of $2.5 \mathrm{~m}$, below the zone of water freeze-up in winter and wave action in the other seasons, on an acidic $(\mathrm{pH} 4.3-5.7)$, mineral $(3.4 \pm 2.6 \%$ of organic matter) and poorly hydrated $(33.8 \pm 9.8 \%)$ substrate with a very variable redox potential $(-228-+396)$. The data come from 144 measurements of each property performed over a period of 3 years (Table 1).

On the basis of water temperature measurements on the plots the following time periods were established for the four seasons in Lake Gacno: spring (April, May; $13.2 \pm 4.0^{\circ} \mathrm{C}$ ), summer (June-August; $21.8 \pm 2.2^{\circ} \mathrm{C}$ ), autumn

TABLE 1. Sediment water properties on experimental plots (arithmetic means with standard deviation, three measurements of each property for each month).

\begin{tabular}{|c|c|c|c|c|c|c|}
\hline Month & $\begin{array}{c}\text { Temperature } \\
{\left[{ }^{\circ} \mathrm{C}\right]}\end{array}$ & $\begin{array}{c}\text { PAR } \\
{[\%]}\end{array}$ & $\mathrm{pH}$ & $\begin{array}{l}\text { Conduct. } \\
{\left[\mu \mathrm{S} \mathrm{cm}^{-1}\right]}\end{array}$ & $\begin{array}{c}\text { Colour } \\
{\left[\mathrm{mg} \mathrm{Pt} \mathrm{dm}^{-3}\right]}\end{array}$ & $\begin{array}{c}\mathrm{HCO}_{3}^{-} \\
{\left[\mathrm{mg} \mathrm{dm}^{-3}\right]}\end{array}$ \\
\hline April & $10.0 \pm 3.0$ & $26.7 \pm 7.1$ & $4.8 \pm 0.1$ & $31.2 \pm 0.7$ & $6 \pm 1$ & $41.2 \pm 6.7$ \\
\hline May & $16.3 \pm 0.6$ & $21.3 \pm 6.8$ & $5.1 \pm 0.2$ & $22.6 \pm 0.7$ & $5 \pm 0$ & $32.3 \pm 3.3$ \\
\hline June & $21.7 \pm 2.5$ & $17.0 \pm 3.6$ & $5.6 \pm 0.5$ & $29.5 \pm 3.7$ & $9 \pm 1$ & $33.7 \pm 15.3$ \\
\hline July & $23.3 \pm 2.1$ & $16.0 \pm 6.1$ & $6.1 \pm 0.2$ & $27.6 \pm 0.8$ & $12 \pm 2$ & $16.9 \pm 1.3$ \\
\hline August & $20.3 \pm 1.1$ & $11.0 \pm 7.8$ & $6.0 \pm 0.2$ & $23.2 \pm 0.5$ & $11 \pm 1$ & $23.0 \pm 3.4$ \\
\hline September & $17.0 \pm 0.1$ & $11.0 \pm 5.3$ & $6.0 \pm 0.1$ & $32.0 \pm 2.1$ & $10 \pm 2$ & $28.2 \pm 4.4$ \\
\hline October & $11.7 \pm 2.1$ & $17.7 \pm 5.0$ & $4.8 \pm 0.5$ & $25.2 \pm 1.7$ & $8 \pm 1$ & $15.9 \pm 1.2$ \\
\hline November & $5.3 \pm 1.5$ & $20.3 \pm 7.0$ & $5.7 \pm 0.3$ & $30.5 \pm 12.5$ & $6 \pm 2$ & $28.2 \pm 4.2$ \\
\hline December & $3.0 \pm 1.7$ & $25.3 \pm 5.7$ & $6.3 \pm 0.6$ & $40.9 \pm 13.7$ & $8 \pm 1$ & $70.2 \pm 24.0$ \\
\hline January & $3.7 \pm 1.1$ & $24.0 \pm 6.9$ & $5.6 \pm 0.2$ & $37.9 \pm 21.8$ & $8 \pm 1$ & $44.1 \pm 10.7$ \\
\hline February & $3.7 \pm 1.5$ & $24.0 \pm 5.0$ & $5.4 \pm 0.1$ & $21.6 \pm 1.9$ & $7 \pm 1$ & $38.4 \pm 3.9$ \\
\hline March & $5.7 \pm 2.1$ & $25.7 \pm 6.5$ & $5.0 \pm 0.1$ & $23.8 \pm 1.0$ & $7 \pm 1$ & $46.5 \pm 6.1$ \\
\hline
\end{tabular}




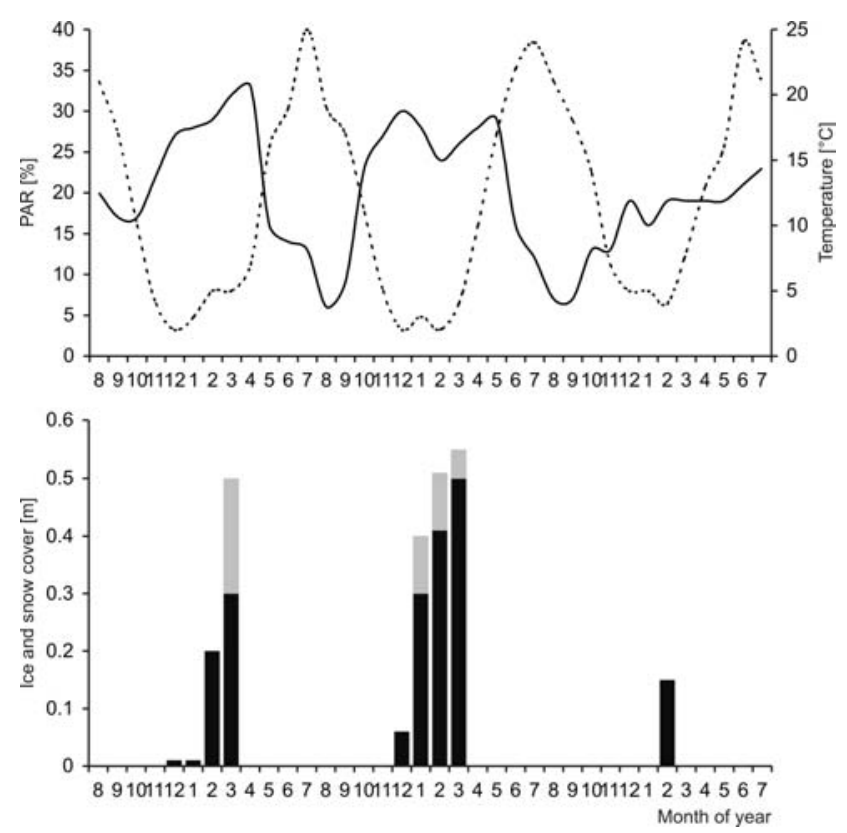

Fig. 1. PAR intensity (continuous line), water temperature (dotted line), ice cover (black bar) and show cover (grey bar) thickness in consecutive months from 8.2004 to 7.2007 .

(September, October; $14.3 \pm 3.2^{\circ} \mathrm{C}$ ) and winter (NovemberMarch; $4.3 \pm 1.7^{\circ} \mathrm{C}$ ). The water temperature in spring (April
$10.0 \pm 3.0^{\circ} \mathrm{C}$, May $16.3 \pm 0.6^{\circ} \mathrm{C}$ ) and autumn (September $17.0 \pm 0.1^{\circ} \mathrm{C}$, October $11.7 \pm 2.1^{\circ} \mathrm{C}$ ) was fairly varied, whereas in summer and winter more uniform. The first (2004/2005) and second (2005/2006) winters were quite frosty, while the third one $(2006 / 2007)$ mild. It is worth mentioning that ice cover, and even ice and snow cover, did not cause any significant decrease in PAR intensity.

Light intensity in the population changed seasonally: it was always the highest in winter and lowest in summer (Fig. 1). In summer water colour values were higher than in the other seasons. Both these water properties indicate that the smallest amount of light reached the population in summer $(\mathrm{p}<0.005)$. This resulted from the massive bloom of filamentous algae from early spring to late autumn, with the maximum intensity in August. The seasonal changes in water $\mathrm{pH}$ and conductivity, as well as $\mathrm{HCO}_{3}^{-}$concentration, were statistically insignificant $(\mathrm{p}>0.05)$. It should be noted that $\mathrm{HCO}_{3}^{-}$concentration was higher in winter $\left(43.2 \pm 16.0 \mathrm{mg} \mathrm{dm}^{-3}\right)$ than in summer $\left(20.3 \pm 13.6 \mathrm{mg} \mathrm{dm}^{-3}\right)$. The seasonal variability of sediment hydration, its $\mathrm{pH}$, conductivity and redox were also statistically insignificant $(\mathrm{p}>0.05)$.

\section{Population dynamics}

The following major changes took place in the population during the 36 months of this study: for the first 24

TABLE 2. Number of Sphagnum denticulatum individuals on plots (I-IV) in the study years, population growth rate (PGR) and stages of its development. Explanations: $\Sigma$ - total of individuals on plots, PGR - population growth rate (individuals $\mathrm{m}^{-2} \mathrm{month}^{-1}$ ).

\begin{tabular}{|c|c|c|c|c|c|c|c|c|}
\hline Year & Month / plot: & I & II & III & IV & $\Sigma$ & PGR & Development stages \\
\hline \multirow{5}{*}{ ষ্ণ } & August & 180 & 80 & 141 & 140 & 541 & - & \multirow{9}{*}{ fluctuations } \\
\hline & September & 182 & 50 & 119 & 147 & 498 & -10.7 & \\
\hline & October & 190 & 112 & 166 & 155 & 623 & +31.2 & \\
\hline & November & 105 & 106 & 152 & 145 & 508 & -28.7 & \\
\hline & December & 99 & 33 & 75 & 103 & 310 & -49.5 & \\
\hline \multirow{12}{*}{ ஜ } & January & 146 & 65 & 109 & 93 & 418 & +27.0 & \\
\hline & February & 85 & 63 & 96 & 138 & 382 & -9.0 & \\
\hline & March & 93 & 57 & 46 & 109 & 305 & -19.3 & \\
\hline & April & 115 & 63 & 35 & 94 & 307 & +0.5 & \\
\hline & May & 374 & 289 & 139 & 191 & 993 & +171.5 & rapid growth \\
\hline & June & 265 & 207 & 94 & 242 & 808 & -46.2 & \multirow{4}{*}{ fluctuations } \\
\hline & July & 221 & 228 & 215 & 210 & 874 & +16.5 & \\
\hline & August & 310 & 269 & 142 & 251 & 972 & +24.5 & \\
\hline & September & 197 & 167 & 85 & 159 & 608 & -91.0 & \\
\hline & October & 496 & 394 & 219 & 451 & 1560 & +238.0 & rapid growth \\
\hline & November & 414 & 365 & 221 & 483 & 1483 & -19.2 & \multirow{9}{*}{ fluctuations } \\
\hline & December & 638 & 447 & 181 & 555 & 1821 & +54.5 & \\
\hline \multirow{12}{*}{ ๖̊ } & January & 509 & 399 & 177 & 533 & 1618 & -50.7 & \\
\hline & February & 486 & 358 & 193 & 518 & 1555 & -15.8 & \\
\hline & March & 501 & 393 & 206 & 584 & 1684 & +32.3 & \\
\hline & April & 613 & 372 & 262 & 581 & 1828 & +36.0 & \\
\hline & May & 659 & 502 & 294 & 591 & 2046 & +54.5 & \\
\hline & June & 682 & 435 & 247 & 703 & 2067 & +5.2 & \\
\hline & July & 529 & 431 & 291 & 572 & 1823 & -61.0 & \\
\hline & August & 74 & 28 & 258 & 614 & 974 & -212.2 & \multirow{6}{*}{ regression } \\
\hline & September & 6 & 0 & 76 & 42 & 124 & -212.5 & \\
\hline & October & 1 & 4 & 11 & 0 & 16 & -27.0 & \\
\hline & November & 1 & 0 & 3 & 3 & 7 & -2.2 & \\
\hline & December & 3 & 1 & 16 & 60 & 80 & +18.3 & \\
\hline \multirow{7}{*}{ 홍 } & January & 1 & 0 & 2 & 0 & 3 & -19.2 & \\
\hline & February & 69 & 24 & 37 & 109 & 239 & +59.0 & \multirow{5}{*}{ regeneration } \\
\hline & March & 34 & 9 & 24 & 84 & 151 & -21.9 & \\
\hline & April & 83 & 47 & 131 & 238 & 499 & +87.4 & \\
\hline & May & 103 & 55 & 202 & 197 & 557 & +14.5 & \\
\hline & June & 183 & 79 & 258 & 381 & 901 & +86.0 & \\
\hline & July & 104 & 46 & 149 & 169 & 468 & -108.2 & fluctuations \\
\hline
\end{tabular}




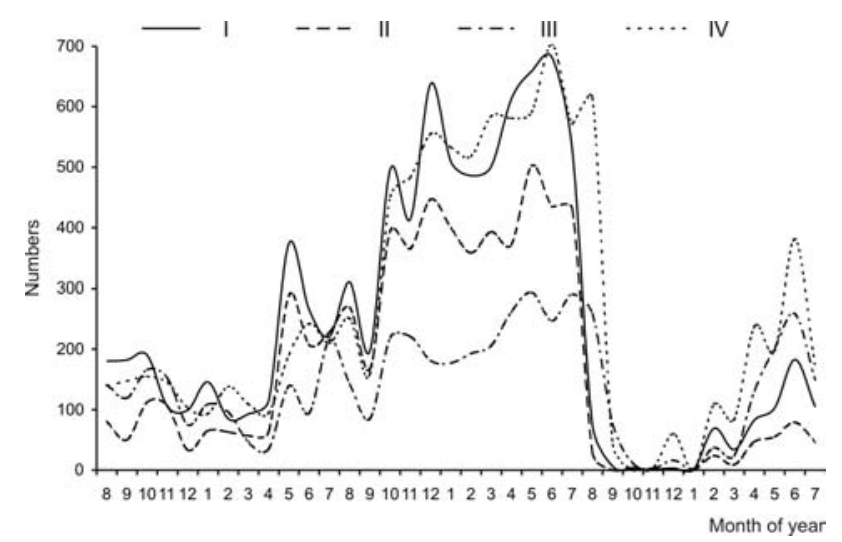

Fig. 2. Population abundance on plots (I-IV) in consecutive months (from 8.2004 to 7.2007$)$.

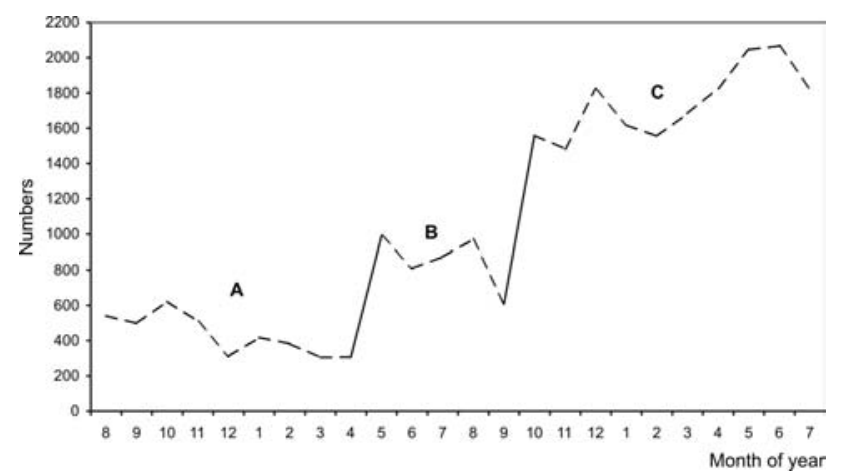

Fig. 3. Stages of abundance fluctuations (A, B, C; dotted line) and rapid population growth (continuous line). Data: the total of individuals on plots I-IV (see Table 2) at the time of population growth stabilising it at a high abundance level (from 8.2004 to 7.2006 ).

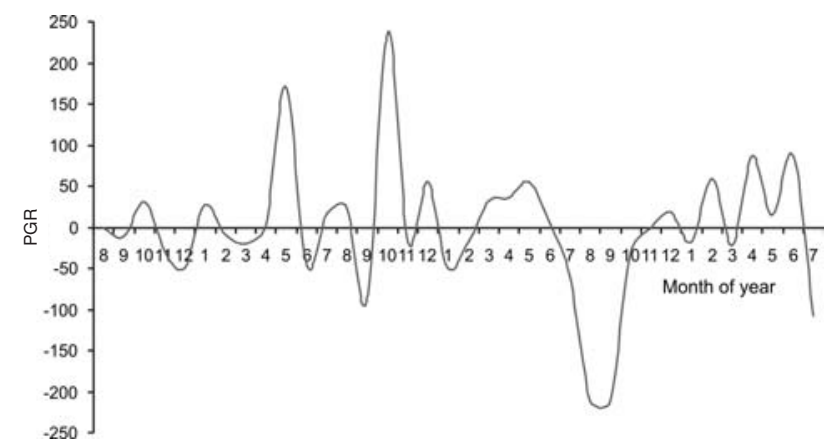

Fig. 4. Variability of the population growth rate (PGR; indiv. $\mathrm{m}^{-2}$ month $^{-1}$ ) over time, from 8.2004 to 8.2007 .

months the abundance increased, in the 26th and 27 th month it decreased dramatically, and in the next 10 months it went up again (Table 2). The analysis of these changes indicates that the first increase, which lasted 24 months (August 2004-July 2006), caused the population to stabilise at a high abundance level, while the second, from February to July 2007, resulted from the population regeneration after its earlier almost complete reduction (Fig. 2). Three periods of changes in population size can be distinguished: intensive growth, regression and regeneration. As these periods differ considerably, each will be analysed separately.

The population abundance increase to the maximum value in June 2006 was the time when the population size stabilised. It lasted from August 2004 to July 2006. The population size changes followed the pattern (Fig. 3): fluctua- tions (August 2004-April 2005), rapid growth (May 2005), fluctuations (June-September 2005), rapid growth (October 2005), fluctuations (November-July 2006). The first fluctuation stage lasted nine, the second four and the third nine months (Fig. 4). The sequence of these stages is interesting to note: a long one followed by a short and long. They appeared and progressed irrespective of time of year, temperature, PAR intensity or chemical properties of water. The calculations indicate that there are no statistically significant correlations between the seasonal changes of water and sediment properties and variations of population abundance. Consequently, the results of the relevant statistical analyses have not been presented in this work.

The first rapid abundance increase occurred in May 2005 (spring), while the second in October (autumn) of the same year. On the plots 307 individuals were recorded in April, 993 in May, 608 in September and 1560 in October (Table 2). Each rapid abundance growth lasted about 30 days and took place at a moderate temperature $\left(16.0^{\circ} \mathrm{C}\right.$ in mid-May, $11.0^{\circ} \mathrm{C}$ in mid-October) and under conditions of fairly intensive light $(>20 \%$ PAR). The first marked increase in water temperature after winter occurred in May $\left(6.5^{\circ} \mathrm{C}\right.$ in mid-April, $16.0^{\circ} \mathrm{C}$ in mid-May), whereas the first significant temperature decrease after summer in October $\left(17^{\circ} \mathrm{C}\right.$ in mid-September, $11.0^{\circ} \mathrm{C}$ in mid-October $)$. In May the population growth rate (PGR) was 171.5 indiv. $\mathrm{m}^{-2}$ month ${ }^{-1}$, whereas in October 238 indiv. $\mathrm{m}^{-2}$ month $^{-1}$.

The abundance fluctuations resulted from dwindling and growing numbers of individuals, that is population mortality rate and reproductiveness. The submerged S. denticulatum does not produce spores, and consequently the recruitment of new individuals to the population is solely vegetative. A certain, probably small, fraction of individuals were moved to the same places or out of them by water.

Young (juvenile) individuals emerged in great numbers only once a year, in spring, that is in April and May (Fig. 5), at a temperature of $6.0-16.0^{\circ} \mathrm{C}\left(11.1 \pm 5.6^{\circ} \mathrm{C}\right)$ and at a high light intensity (19.6-30.0\% PAR; $26.8 \pm 6.8 \%$ PAR) just after ice break-up and before the massive bloom of filamentous green algae. Only one cohort of young individuals appeared during each year. They formed from fragments of leafless shoots lying on the sediment surface or directly under its thin layer in winter. A water temperature increase and higher light intensity in spring stimulated the growth of the shoots.

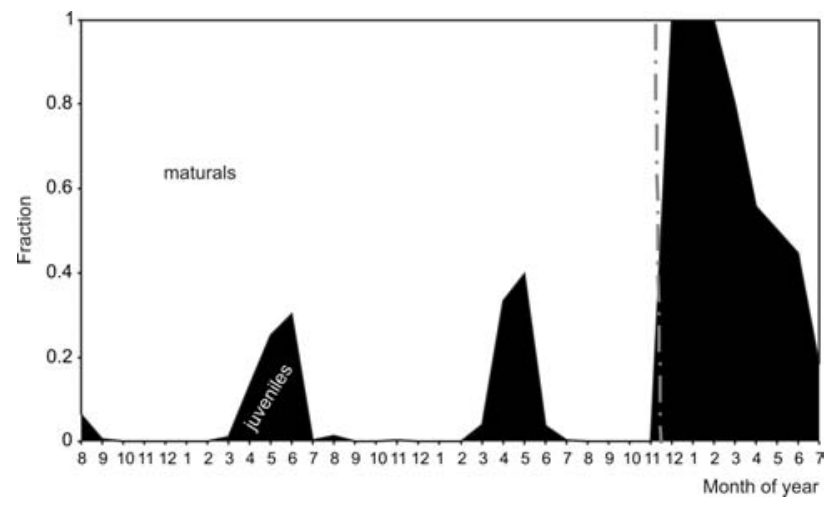

Fig. 5. Fraction of juvenile (black) and mature (white) individuals in the stage of fluctuating changes in population abundance (to the left of the dotted line) and the phase of population regeneration (to the right of this line) in consecutive months from 8.2004 to 7.2007 . 


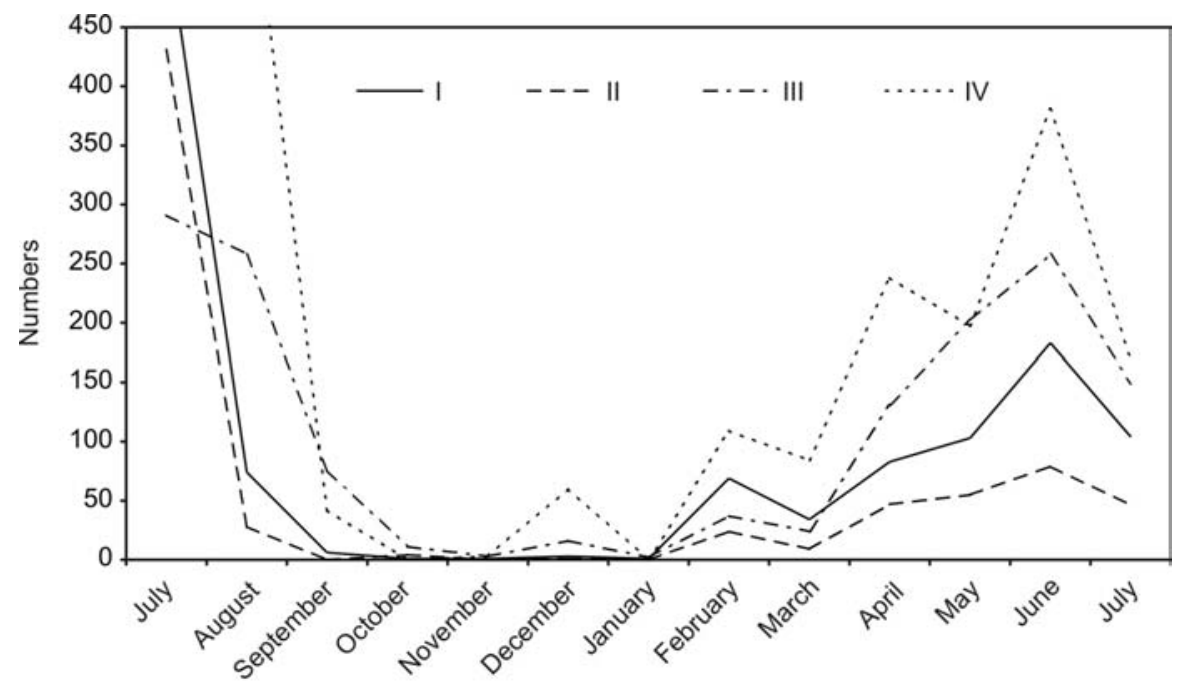

Fig. 6. Population regression (August $2006-$ January 2007) and regeneration (February 2007 - June 2007) on permanent plots (I-IV).

\section{Regression and regeneration of the moss carpet}

On the plots 1823 individuals grew in July 2006, 974 in August, 124 in September and only seven in November (Table 2). After six months from the occurrence of regression signs the population almost completely disappeared: in January 2007 only three individuals were left. In August 2006 the population growth rate (PGR) was -212.2 indiv. $\mathrm{m}^{-2}$ month $^{-1}$, reaching a similar value in September. The population regression, which lasted from August 2006 to January 2007, and the disintegration of the moss carpet were brought about by the massive bloom of filamentous green algae. They appeared in the summer of each year, albeit with less intensity than in 2006 and less severe consequences for the population of $S$. denticulatum.

The process of regeneration began in February 2007 (Table 2) at a water temperature of $3.0^{\circ} \mathrm{C}$ and light intensity PAR of $19 \%$ in the presence of ice cover $(0.15 \mathrm{~m})$. In March water temperature was similar to that in February, ice cover was slightly thicker $(0.50 \mathrm{~m})$ and snow cover thinner $(0.05 \mathrm{~m})$. A considerable amount of light reached the population (32\% PAR). From April the population abundance gradually increased and towards the end of June almost doubled. In July (the last study month) the abundance decreased (Fig. 6) as a result of the filamentous green algae emergence, but not to such an extent as in the previous year.

The population regenerated itself from leafless shoots, which played the role of vegetative propagules. They were fragments (remains) of individuals growing on the plots before the regression stage. In the spring (April, May) of 2005 and 2006 juvenile individuals formed a fraction of $30-40 \%$, whereas in the regeneration stage (from February 2007 to the end of the study) they made up almost the whole population (Fig. 5, to the right of the vertical dotted line). The population quickly regenerated: in April and June 2007 the population growth rates (PGR) belonged to the highest over the three study years (Table 2).

\section{DISCUSSION}

The studied population occurs in a small and softwater lake with isoetids, including Lobelia dortmanna L., Isoëtes lacustris L. and Luronium natans (L.) Raf. The catchment, the same as its vicinity, is located on an outwash plain from the time of the last glaciation and is covered with very acidic soils dominated by pine forest (Chmara 2008). In such a landscape Lake Gacno must be acidic, and Sphagnum denticulatum is a natural element of its vegetation. There are no significant reasons to assume that the occurrence of this plant is connected with human-induced acidification, as was the case in lakes described by Grahn et al. (1974); Grahn (1977); Roelofs (1983) or Raven (1988).

The moss carpet in Lake Gacno, which consisted mainly of $S$. denticulatum, is spatially variable: short and sparse to a depth of $1.5 \mathrm{~m}$ or high and dense between 2.0 and $5.5 \mathrm{~m}$. It is similar to the one occurring in Lake Grane Langsø, where Riis and Sand-Jensen (1997) studied the effect of depth, light, temperature and carbon dioxide on the growth and photosynthesis of aquatic mosses (Sphagnum subsecundum and Drepanocladus exannulatus). It also resembles the moss carpets in three small and clear-water lakes in nortwestern Russia (Karelia Republic) described by Ilyashuk (2002), where growth and production of mosses at various depths were determined. In Lake Gacno, however, the attention was focused on the changes in the population abundance of an aquatic moss ( $S$. denticulatum) in seasonally changing temperature and light.

In Lake Gacno, at a depth of $2.5 \mathrm{~m}$, the $S$. denticulatum population is fairly well-lit (11.0-26.7\% PAR), occupies an acidic $(\mathrm{pH} 4.3-5.7)$, mineral $(3.4 \pm 2.6 \%$ of organic matter) and poorly hydrated $(33.8 \pm 9.8 \%$; Table 1$)$ substrate, which becomes more organic and half-liquid at a depth of 2.5-5.5 m. The population in Lake Gacno occurs under similar conditions to those in Danish Lake Grane Langsø and the lakes described in Karelia. Therefore the possibility that similar mechanisms of changes in population abundance occur in all these lakes cannot be excluded.

In summer, especially after a warm spring, the structure and spatial organisation of the $S$. denticulatum population were disturbed by a massive bloom of filamentous algae. In late autumn there was a much smaller amount of the green algae, as most of them do not tolerate low temperatures (Ellis-Evans and Walton 1990). Nevertheless, a fraction of them was present in Lake Gacno also in winter. A similar phenomenon was observed by Hawes $(1989,1990)$ in freshwater streams on Signy Island (Antarctica). On the other hand, however, a complete disappearance of the $S$. denticu- 
latum population in Lake Krasne, which is a few dozen kilometres from Lake Gacno, was caused by abrupt sediment resuspension after a considerable decrease in water level (Szmeja 2006). In both these lakes the population regenerated quickly: in Lake Krasne the process was in progress for two years, and in Lake Gacno approx. 30\% of the population of the main dominant species ( $S$. denticulatum) was recreated within five months.

The fact that this plant grows fast might have substantially contributed to the short regeneration time of the $S$. denticulatum population (and the moss carpet, this plant being its main component). The results obtained by Riis, SandJensen (1997) and Ilyashuk (2002) confirm this assumption. Annual growth rate of moss shoots in Karelian lakes at a depth of $6.5 \mathrm{~m}$ was $45.3 \pm 5.9 \mathrm{mg}$ air-dry weight shoot ${ }^{-1}$ year $^{-1}$ (Ilyashuk 2002), while in Lake Grane Langsø at the same depth $17.6 \pm 2.2 \mathrm{mg}$ air-dry weight shoot $^{-1}$ year $^{-1}(\mathrm{Ri}$ is, Sand-Jensen 1997). In both cases the annual growth rate of shoots, for a perennial and evergreen plant like this one, is high, which is proved by its elongation rate in Lake Grane Langsø $\left(251 \pm 7 \mathrm{~mm} \mathrm{shoot}^{-1}\right.$ year $\left.^{-1}\right)$ and in the lakes of Karelia (189 $\pm 7 \mathrm{~mm}$ shoot $^{-1}$ year $\left.^{-1}\right)$. In the Danish lake mosses had a relatively fast growth rate $\left(90-250 \mathrm{~mm} \mathrm{shoot}^{-1}\right.$ year $\left.^{-1}\right)$ and were short lived (0.7-2.9 years). What is more, in deep water they grew faster than in shallow water. According to Riis and Sand-Jensen (1997), the fast growth of mosses in deep waters can be accounted for by lower temperature, extensive $\mathrm{CO}_{2}$, supersaturation and nutrient enrichment in the hypolimnion during summer stratification. The short regeneration time of the population after the massive bloom of filamentous green algae confirms the fact that $S$. denticulatum grows fast. The regeneration process began in February 2007 (3.7 $\pm 1.5^{\circ} \mathrm{C}$, PAR 19\%). Over the three spring months, from April $\left(10.0 \pm 3.0^{\circ} \mathrm{C}\right.$ and $26.7 \pm 7.1 \%$ PAR $)$ to June $\left(21.7 \pm 2.5^{\circ} \mathrm{C}\right.$ and $17.0 \pm 3.6 \%$ PAR) the population abundance almost doubled (Table 2, Fig. 6). During the rapid abundance increase in May and October 2005 the rates of population growth (PGR) were the highest: 171.5 shoots $\mathrm{m}^{-2}$ month $^{-1}$ in May and as many as 238 shoots $\mathrm{m}^{-2}$ month $^{-1}$ in October (Table 2). It is worth mentioning that over the three years of observations such rapid population abundance growths occurred only twice. Each of them lasted about 30 days and took place at a moderate temperature and fairly intensive light (Table 1, Fig. 4).

The fluctuations of population abundance are the outcome of reproductiveness and mortality. Submerged S. denticulatum individuals do not produce spores, and consequently the recruitment of young individuals to the population is solely vegetative. A certain fraction of individuals, probably a small one, is carried to the same places or out of them by water movement, especially in the shallow littoral. It is significant that young individuals appear in great numbers only once a year in spring, that is in April and May (Fig. 5), at a temperature of $6.0-16.0^{\circ} \mathrm{C}$ and relatively high light intensity (19.6-30.0\% PAR) just after ice break-up and before the summer bloom of filamentous green algae. Other boreal, subboreal and alpine coldwater plants, e.g. those studied by Gacia et al. (1994) in the Eastern Pyrenees, might be characterised by similar phenology of growth and development.

In the S. denticulatum population there was only one cohort of juvenile individuals a year: in spring (March - June) (Fig. 5). They formed from fragments of leafless shoots ly- ing on the sediment surface or just under its thin layer in winter. A temperature increase and higher light intensity in spring probably stimulated their growth. The presence of leafless but live shoots that are capable of regeneration indicates that the plant is adapted to seasonally low light intensity and long-lasting low temperatures. In Lake Gacno the water temperature at a depth of $2.5 \mathrm{~m}$ was only $4.3 \pm 1.7^{\circ} \mathrm{C}$ from November to March, that is for 5 months a year. As shoot elongation takes place also in winter (Riis and Sand-Jensen 1997; Ilyashuk 2002) and the population abundance increases at this time of year (Table 2, Figs 2-4), leafy shoots do not go through diapause because of low temperatures. Priddle's (1980) observations confirm this statement. Diapause can be caused by too low light intensity. In Lake Gacno such a situation occurred always in summer as a consequence of the massive bloom of filamentous green algae. They form thick mats, are a light filter and compete for nutrients and free space (Ozimek et al. 1991; Szmeja 1994, 2006). Under such conditions the population of $S$. denticulatum could regenerate thanks to vegetative reproduction, a viable propagule bank (leafless shoots) and all-year-round growth of this plant.

\section{CONCLUSIONS}

The population of $S$. denticulatum has its own pattern of abundance variations, which is disturbed by a massive bloom of filamentous algae in summer, especially after a warm spring. The population regeneration which follows is fast. Over the three years of observations periods of rapid abundance increase were short and occurred at low temperatures (in spring and autumn) and intensive light (Table 1, Fig. 4).

The regeneration time was short due to the fact that shoots of this plant grow fast, which was mentioned by Riis, Sand-Jensen (1997) and Ilyashuk (2002). Only one (spring) cohort of juvenile individuals a year is observed in the population (Fig. 5). The cohort grows from sections of leafless shoots which lie on the sediment surface or under its thin layer in winter. The development of these shoots is stimulated by a temperature rise and higher light intensity in spring. The fact that the shoots grow all year round, vegetative reproduction of this plant and the diaspore (leafless shoot) bank deposited on the sediment surface are factors that favour fast regeneration of the population.

\section{ACKNOWLEDGEMENTS}

I would like to extend my thanks to Mr Marek Merdalski, MSc, for the collection of materials and Ms Emilia Pokojska, M.A., for translating this text into English. The study was done within the framework of the project 2 P04G 00127 financed by the Ministry of Science and Higher Education.

\section{LITERATURE CITED}

AKIMOTO M., SCHIMAMOTO Y., MORISHIMA H. 1998. Population genetic structure of wild rice Oryza glumaepatula distributed in the Amazon flood area influenced by its life-history traits. Mol. Ecol. 7: 1371-1381. 
ARTS G.H.P. 1987. Historical development and extent of acidification of shallow soft waters in the Netherlands. In: Air pollution and ecosystems. Mathy P. (ed.). Proceedings of an international symposium held in Grenoble, France, 18-22 May 1987: 928-933.

BANAŚ K. 2002. Impact of humic substances on Sphagnum denticulatum habitats. Acta Soc. Bot. Pol. 71: 63-69.

BARRETT S.C.H., ECHERT C.G., HUSBAND B.C. 1993. Evolutionary processes in aquatic plant populations. Aquat. Bot. 44: $105-145$

CATLING P.M., FREEDMAN B., STEWART C., KEREKES J.J., LEFKOVITCH L.P. 1986. Aquatic plants of acid lakes in Kejimkujik National Park, Nova Scotia; floristic composition and relation to water chemistry. Can. J. Bot. 64: 724-729.

CHAMBERS P.A., KALFF J. 1985. Depth distribution and biomass of submersed aquatic macrophyte communities in relation to Secchi depth. Can. J. Fish. Aquat. Sci. 42: 701-709.

CHMARA R. 2008. Przyczyny zróżnicowania struktury roślinności podwodnej w jeziorach na obszarach sandrowych Borów Tucholskich. Dr. Diss., University of Gdańsk. (in Polish)

EATON A.D., CLESCERI L.S., RICE E.W., GREENBERG A.E. 2005. Standard methods for the examination of water and wastewater. American Public Health Association, Washington.

ELLIS-EVANS J.C., WALTON D. 1990. The process of colonization in Antarctic terrestrial and freshwater ecosystems. Proceedings of the NIPR Symposium on Polar Biology 3: 1511990.

GACIA E., BALLESTEROS E., CAMARERO L., DELGADO O., PALAU A., RIERA J.L., CATALAN J. 1994. Macrophytes from lakes in the eastern Pyrenees: community composition and ordination in relation to environmental factors. Freshwat. Biol. 31: 73-81

GAO L.Z., HONG S.G.D.Y. 2000. Low levels of genetic diversity within populations and high differentiation among populations of a wild rice, Oryza granulata Nees et Arn. ex Watt., from China. Int. J. Plant Sci. 161: 691-697.

GORNALL R.J., HOLLINGSWORTH P.M., PRESTON C.D. 1998. Evidence for spatial structure and directional gene flow in a population of an aquatic plant, Potamogeton coloratus. Heredity 80: 414-421.

GRAHN O., HULTBERG H., LANDNER L. 1974. Oligotrophication a self accelerating process in lake subjected to excessive supply of acid substances. Ambio 3: 93-94.

GRAHN O. 1977. Macrophyte succession in Swedish lakes caused by deposition of airborne acid substances. Water Air Soil Pollut. 7: 295-306.

HAWES I. 1989. Filamentous green algae in freshwater streams on Signy Island, Antarctica. Hydrobiologia 172: 1-18.

HAWES I. 1990. Effects of freezing and thawing on a species of Zygnema (Chlorophyta) from the Antarctic. Phycologia 29: 326-331

HERMANOWICZ W., DOJLIDO J., DOŻAŃSKA W., KOZIOROWSKI B., ZERBE J. 1999. Fizyczno-chemiczne badanie wody i ścieków. Arkady, Warszawa (in Polish).

HOFSTRA D.E., ADAM K.D., CLAYTON J.S. 1995. Isozyme variation in New Zealand populations of Myriophyllum and Potamogeton species. Aquat. Bot. 52: 121-131.

ILYASHUK B.P. 2002. Growth and production of aquatic mosses in acidified lakes of Karelia Republic, Russia. Water Air Soil Pollut. 135: 285-290.
ŁOMNICKI A. 1999. Wprowadzenie do statystyki dla przyrodników. Wydawnictwo Naukowe PWN, Warszawa. (in Polish)

MURPHY K.J. 2002. Plant communities and plant diversity in softwater lakes of northern Europe. Aquat. Bot. 73: 287-324.

OZIMEK T., PIECZYŃSKA E., HANKIEWICZ A. 1991. Effect of filamentous green algae on submerged macrophytes growth: a laboratory experiment. Aquat. Bot. 41: 309-315.

PRIDDLE J. 1980. The production ecology of benthic plants in some Antarctic lakes. I. In situ production studies. J. Ecol. 68: 141-153.

RAVEN P.J. 1988. Occurrence of Sphagnum moss in the sublittoral of several small oligotrophic lakes in Gallaway, southwest Scotland. Aquat. Bot. 30: 223-230.

RIIS T., SAND-JENSEN K. 1997. Growth reconstruction and photosynthesis of aquatic mosses: influence of light, temperature and carbon dioxide at depth. J. Ecol. 85: 359-372.

ROELOFS J.G.M. 1983. Impact of acidification and eutrophication on macrophyte communities in soft waters in the Netherlands. 1. Field obsevations. Aquat. Bot. 17: 139-155.

SAND-JENSEN K., SØNDERGAARD M. 1981. Phytoplankton and epiphyte development and their shading effect on submerged macrophytes in lakes of different nutrient status. Int. Revue Ges. Hydrobiol. 66: 529-552.

SANTAMARÍA L. 2002. Why are most aquatic plants widely distributed? Dispersal, clonal growth and small-scale heterogeneity in a stressful environment. Acta Oecol. 23: 137-154.

SRIVASTAVA D.S., STAICER C.A., FREEDMANN B. 1995. Aquatic vegetation of Nova Scotia lakes differing in acidity and trophic status. Aquat. Bot. 51: 181-196.

SZAŃKOWSKI M., KŁOSOWSKI S. 2004. Distribution and habitat conditions of the phytocoenoses of Sphagnum denticulatum Bridel and Warnstorfia exannulata (B., S. \& G.) Loeske in Polish Lobelia lakes. Acta Soc. Bot. Pol. 73: 266-262.

SZMEJA J. 1994. An individual's status in populations of isoetid species. Aquat. Bot. 48: 203-224.

SZMEJA J. 2000. Tendencies of changes in the flora and vegetation structure of Pomeranian lakes under the influence of humic substances. In: Mechanisms of anthropogenic changes of the plant cover. Jackowiak B., Żukowski W. (eds). Bogucki Wydawnictwo Naukowe, Poznań, pp. 85-98.

SZMEJA J. 2006. Przewodnik do badań roślinności wodnej. Wydawnictwo Uniwersytetu Gdańskiego, Gdańsk. (in Polish)

SZMEJA J., BOCIĄG K. 2004. The disintegration of populations of underwaterplants in soft water lakes enriched with acidic organic matter. Acta Soc. Bot. Pol. 73: 165-173.

SZMEJA J., CLÉMENT B. 1990. Comparaison de la structure et du déterminisme des Littorelletea uniflorae en Poméranie (Pologne) et en Bretagne (France). Phytocoenologia 19: 123-148.

SZMEJA J., BAZYDŁO E., URUSKA A. 2001. Role of humic substances in the determination of Sphagnum denticulatum Brid. and Myriophylum spicatum L. habitat conditions. Pol. J. Ecol. 49: 101-113.

TOIVONEN H., HUTTUNEN P. 1995. Aquatic macrophytes and ecological gradients in 57 small lakes in southern Finland. Aquat. Bot. 51: 197-221.

WETZEL R.G., LIKENS G.E. 1991. Limnological Analyses. Springer Verlag, New York, Heidelberg, London, Paris, Tokyo, Hong Kong, Barcelona, Budapest. 